\title{
Lastensuojelusta ja lapsen oikeudesta kunnioitukseen
}

Katariina Hemming

\section{Johdanto}

I apset muodostavat ison osan yhteiskuntaa, väestöä, kansakuntaa, asukkaita ja kansalaisia. He ovat pysyviä kumppaneita." (Korczak 2011, 57.)

Kantelut eduskunnan oikeusasiamiehelle lastensuojelusta ja sijaishuollosta ovat moninkertaistuneet viime vuosina. Lastensuojelulaitoksiin tehdyt tarkastukset ja kesällä 2020 julkaistut tarkastusraportit paljastivat, että sijaishuollossa käytetään lasten oikeuksia polkevia, lasta loukkaavia ja jopa alistavia kasvatuskeinoja (ks. esim. EOAR/5930/2019). Tarkastusraporttien perusteella voisi todeta, että samalla, kun lapset ovat alkaneet tiedostaa oikeuksiaan, kasvattajat tuskailevat kasvatuskäytäntöjen kanssa, jotka ovat kuin ajalta, jolloin iltasadussa opetettiin, että peukaloa imevältä lapselta leikataan peukalot irti! Lastensuojelusta ja sijaishuollosta kantautuneet negatiiviset uutiset - ja yleisesti yhteiskunnassa koventuneet asenteet - ovat saaneet minut usein miettimään erästä Suomessa vähemmän esillä ollutta pedagogia. Kyseessä on Janusz Korczak (1878-1942), syntyjään Henryk Goldszmit, jonka ajatuksiin haluan tutustuttaa teidät tarkemmin tässä puheenvuorossa. 


\section{Kuka oli Janusz Korczak?}

Janusz Korczak oli puolanjuutalainen lastenlääkäri, orpokodin johtaja, pedagogi ja kirjailija, jonka intohimona oli lasten oikeuksien ajaminen. Korczak eli ajanjaksona, jota on kutsuttu yhdeksi maailman historian väkivaltaisimmista: hänen elinaikanaan Eurooppaa raatelivat molemmat maailmansodat. Elämänsä aikana hän näki tuhansittain sodan jalkoihin hylättyjä, tapettuja ja nälkään sekä sairauksiin kuolevia lapsia. Erityisen läheltä Korczak todisti lasten kärsimyksiä natsien juutalaisvainoissa, joiden seurauksena Euroopassa kuoli arviolta 1,5 miljoonaa lasta. Korczak oli syystäkin huolissaan lapsiin kohdistuvista julmuuksista ja mielivaltaisuudesta. Hän kantoi huolta erityisesti niiden pitkäaikaisista vaikutuksista yhteiskuntien väkivaltaistumiseen. (Eichsteller 2011; Hammarberg 2009.)

Korczak tunnetaan parhaiten pedagogiikastaan ja toiminnastaan orpokodin johtajana Varsovassa toisen maailmansodan kynnyksellä ja sen aikana. Korczakin pedagogiikan pääpaino oli yhteisökasvatuksessa, mutta hän otti kantaa myös lasten oikeuksiin yhteiskunnallisesti ja kansainvälisesti. Hänen vaikutuksensa näkyy esimerkiksi YK:n lapsen oikeuksien sopimuksessa. Korczak asui orpokodissa yhdessä lasten kanssa ja teki samalla valtavat määrät havaintoja ja kirjallisia muistiinpanoja lasten kasvusta, kehityksestä ja kasvatusmenetelmistä. Hänellä oli kyky tehdä ja nähdä asioita toisin, ja häntä on hyvästä syystä kuvattu muun muassa rakkauden ja kunnioituksen pedagogiksi. (Eichsteller 2011, 497; Hämäläinen 2001; Lewowicki 2000.)

\section{Mitä suomalainen sijaishuolto voisi oppia Korczakilta 2020-luvulla?}

Korczakin kirjoituksissa on paljon esimerkkejä siitä, kuinka lapset yleensä nähdään yhteiskunnan jäseninä vain aikuisten kautta ja aikuisten tekojen kohteena. Lapsen elämän ainutlaatuisuutta ja ihmisarvoa ei tunnisteta. Korczak osaa havainnollistaa, että elämä pienenä on vaivalloista. Niinkin arkiset asiat kuin rappuset, huonekalut tai mahdollisuus kurkistaa ulos ikkunasta on tehty siten, että lapsi joutuu kiipeämään tai kurkottelemaan. Milloin tahansa voi tulla joku vahvempi ja nostaa juuri tuolille kiivenneen lapsen takaisin lattialle. Korczakin mukaan lapsen saavutusten vähätteleminen ja voimattomuuden tunteen ruokkiminen kasvattaa ainoastaan kunnioittamaan vahvempaa ja tottelemaan - sekä erityisesti väheksymään heikompiaan. (Korczak 2011, 13-14.) Jos kuitenkin haluamme, että lapsesta kasvaa tiedostava ja välittävä persoona, meidän tulee nähdä 
lapsuus ja nuoruus tärkeänä osana ihmiselämää, ei välivaiheena aikuisuuteen. Lapsen ilot, surut, mielipiteet ja olemassaolo ylipäätään ovat yhtä lailla todellisia ja yhtä tärkeitä kuin aikuisten. (Korczak 2011, 22; Hartman 2009, 14; Vucic 2017, 162.)

Eduskunnan oikeusasiamiehen tarkastuskertomuksen mukaan sijaishuollon laitoksista löytyi puutteita lasten ja nuorten kohtelussa ja kuulemisessa (EOAR/5930/2019). Kasvattajien mielivaltaisuus näyttäytyy lapsille ja nuorille esimerkiksi päätöksinä ja rajoitustoimenpiteinä, joita ei perustella mitenkään. Jos nuoren puhelinaikoja rajataan hyvästä syystä, miksi meidän aikuisten on niin vaikea kertoa näitä perusteluita lapselle? Lapsella ja nuorella on oikeus vastustaa kasvattajien päätöksiä, kertoa mielipiteensä (usein vielä varsin ponnekkaasti) ja samalla tulla kuulluksi. Kasvattajan tehtävänä on antaa mielenilmauksille tilaa ja olla väheksymättä niitä - ja samalla turvata suotuisat kasvuolosuhteet.

Sijaishuollossa ongelmia aiheuttaa myös henkilökunnan taitamattomuus ja eriarvoistava suhtautuminen lapsiin ja nuoriin. Korczak reflektoi jatkuvasti sekä omaa että henkilökunnan toimintaa kasvattajina. Hänen edistyksellisiin toimintapoihinsa kuului orpokodin opettajien moraalinen koulutus, ja hän vaati henkilökunnaltaan, että lapsia tuli puhutella ja kohdella kunnioittavasti. Myös demokratiakasvatuksella oli keskeinen rooli orpokotien toiminnassa. Niissä julkaistiin esimerkiksi omaa lehteä, jonka lapset toimittivat. Lasten parlamentti sääti orpokodin säännöt ja vaikutti muun muassa opetushenkilökunnan palkkaamiseen. Ainakin yhden opettajan tiedetään saaneen lopputilin lasten päätöksellä, ja myös Korczak itse joutui lasten tuomioistuimen eteen. Korczakin toiminta kasvattajana ja orpokodin johtajana oli hänen elinaikanaan ennenkuulumatonta. (Hartman 2009, 17.) Siinä on paljon sellaista, mistä voisi ottaa oppia tämänkin päivän lastensuojelulaitoksissa.

\section{Lopuksi}

Natsien miehitettyä Varsovan myös orpokoti joutui muuttamaan gettoon. Poikkeusoloista huolimatta orpokodissa jatkettiin päivittäisiä rutiineja ja muun muassa käytiin koulua. Kurjistuneista elinolosuhteista huolimatta Korczak ylläpiti toivoa. Kuolemanmarssille kohti Treblinkan tuhoamisleiriä lapset pukivat päälleen parhaat vaatteensa ja ottivat mukaansa rakkaat lelunsa aivan kuin olisivat lähdössä lomamatkalle. Lasten mukana kulkivat Korczak, orpokodin johtajatar Stefania Wilczynska sekä kymmenen orpokodin työntekijää. 
Elämme tällä hetkellä maailmanlaajuisesti poikkeusoloja, jotka ovat jatkuneet jo lähes kaksi vuotta. COVID-19-pandemia on jälleen kerran osoittanut, että lapset kärsivät kriiseissä usein niiden välillistä vaikutuksista. Koronavirus ei tyypillisesti sairastuta lapsia vakavasti, mutta epidemian leviämisen estämiseksi määrätyt rajoitustoimet ovat vaikuttaneet monen lapsen elämään elämänlaatua heikentävästi. Poikkeusoloilla ei kuitenkaan voida selittää lastensuojelussa ja sijaishuollossa pitkäaikaisesti ilmenneitä puutteita ja ongelmia.

Lastensuojelua ja sijaishuoltoa kuormittavat monet tekijät, jotka eivät lähtökohtaisesti ole lastensuojelullisia ongelmia. Esimerkiksi mielenterveyttä edistäviä palveluita on niukasti lasten ja nuorten saavutettavissa, minkä vuoksi sijaishuollossa huolehditaan myös lapsista, jotka kaipaisivat kipeästi psykiatrista hoitoa. Lastensuojelun työntekijöiden resurssien vähäisyys venyttää sekä sosiaalityöntekijän tapaamisaikojen välejä että päätöksentekoa heikentäen lasten oikeusturvaa. Eri toimijoiden välille ei synny luottamusta, koska ei ole aikaa kohdata. Ongelmia aiheuttavat myös epäyhdenmukaiset lastensuojelukäytännöt eri kunnissa. Ne asettavat perheitä eriarvoiseen asemaan ja hämmentävät myös lastensuojelun ruohonjuuritason kasvatus- ja hoitotyötä tekeviä henkilöitä. Tällöin on vaarana, että toiminnan keskiössä oleva lapsi ja hänen oikeutensa ja arvonsa unohtuvat. Meidän tehtävämme on kulkea näiden lasten rinnalla.

Lapsen esittämä kritiikki aikuisia kohtaan voi olla pelottavaa, joten sen kieltäminen ja torjunta ovat inhimillisiä reaktioita. Eduskunnan oikeusasiamiehen tarkastuskertomuksista näkyy, että lastensuojelulaitosten henkilökunta epäilee lasten kertomusten luottavuutta ja jopa syyttää heitä valehtelusta (ks. esim. EOAR/4099/2018). Tällaisessa asenneilmapiirissä ja kasvuympäristössä lapsen oikeuksien toteutuminen on mahdotonta. Niiden turvaaminen on aina lopulta meidän aikuisten vastuulla ja ensisijainen tehtävä - myös silloin, kun lapsi käyttäytyy mielestämme väärin. Korczak toteaa:

Vuosien työ on osoittanut yhä selkeämmin, että lapset ansaitsevat osakseen kunnioitusta, luottamusta ja hyväntahtoisuutta. Heidän kanssaan on helppo olla valoisassa ilmapiirissä, jota sävyttävät lempeät odotukset, iloinen nauru, innokkaat ensi askeleet ja yllätykset, selkeät ja mutkattomat ilonaiheet. Silloin työ sujuu joutuisasti ja kantaa hedelmää. (Korczak 2011, 46-47.) 


\section{LÄHTEET}

Eduskunnan oikeusasiamiehen ratkaisu EOAR/4099/2018. Saatavissa https://www.oikeusasiamies.fi/r/fi/ratkaisut/-/eoar/4099/2018 (haettu 23.10.2021).

Eduskunnan oikeusasiamiehen ratkaisu EOAR/5930/2019. Saatavissa https://www.oikeusasiamies.fi/r/fi/ratkaisut/-/eoar/5930/2019 (haettu 29.9.2020).

Eichsteller, G. 2011. Janusz Korczak - his legacy and its relevance for children's rights today. Teoksessa M. D. A. Freeman (Ed.) Children's rights: progress and perspectives. Essays from the International Journal of Children's Rights. Boston: Leiden, 496-514.

Hammarberg, T. 2009. Foreword: Korczak - our teacher on the rights of the child. Teoksessa Janusz Korczak. The Child's Right to Respect. Janusz Korczak's legacy - Lectures on today's challenges for children. Strasbourg: Council of Europe, 5-9. Saatavissa https://www.coe.int/t/commissioner/source/prems/PublicationKorczak_ en.pdf (haettu: 16.10.2020).

Hartman, S. 2009. Janusz Korczak's legacy: an inestimable source of inspiration. Teoksessa Janusz Korczak. The Child's Right to Respect. Janusz Korczak’s legacy - Lectures on today's challenges for children. Strasbourg: Council of Europe, 13-22. Saatavissa https://www.coe.int/t/commissioner/source/prems/PublicationKorczak_ en.pdf (haettu: 1.10.2020).

Hämäläinen, J. 2001. Janusz Korczak (1878-1942). Sosiaalipedagoginen aikakauskirja 2 (2), 141-144.

Korczak, J. 2011. Lapsen oikeus kunnioitukseen. Ilmestynyt alun perin 1929. Helsinki: Basam Books.

Lewowicki, T. 2000. Janusz Korczak (1878-1942). Prospects. The quarterly review of comparative education 24 (1/2), 37-48.

Vucic, B. 2017. The colonization of childhood. The critical pedagogy of Janusz Korczak. Teoksessa A. Odrowąż-Coates \& S. Goswami (Eds.) Symbolic violence in socio-educational contexts. A post-colonial critique. Warsaw: Wydawnictwo Akademii Pedagogiki Specjalnej, 161-180. 
258 - Sosiaalipedagoginen aikakauskirja, vuosikirja 2021, vol. 22 